\title{
To Praise the Estate Tax, Not To Bury
}

It*

\section{Michael J. Graetz†}

For several decades, total revenues raised by estate and gift taxes have roughly equalled those raised by excise taxes on alcohol and tobacco. ${ }^{1}$ Yet no law journal has ever asked me to write on alcohol or tobacco excise taxes. The law firms of America do not routinely have divisions devoted to excise tax planning. We do not hear of the suffering of widows and orphans (or even of farmers and small businesses) because of alcohol and tobacco taxes. Philosophers and economists do not routinely debate the merits of such taxes. Perhaps most significantly, increases in such excise taxes do not arouse fears that we are about to eliminate the concept of private property in this country and embrace socialism, or even communism. The estate tax, however, evokes just such responses. ${ }^{2}$

\section{Recent Trends in Estate Taxation}

A review of the most recent history of the estate tax suggests special ironies. Just seven years ago, in 1976, after nearly thirty years of neglect, Congress adopted a series of revisions intended to make the estate and gift taxes apply on a more regular and uniform basis; ${ }^{3}$ these reforms had been

* An earlier version of this Article was presented as "The Estate Tax-Wither or Whither?," the Fourteenth Mortimer H. Hess Memorial Lecture before the Association of the Bar of the City New York City on May 11, 1983. The author wishes to thank Valerie Lambiase and Barbara McDowell for research assistance and Professor Jerry L. Mashaw for helpful comments.

$\dagger$ Professor of Law, Yale University.

1. U.S. Bureau of the Gensus, Statistical Abstract of the United States: 1981, at 256 (102d ed. 1981) [hereinafter cited as 1981 Statistical ABSTRACT].

Actually, the alcohol and tobacco excise taxes together have consistently raised several billion more dollars per year than have the estate and gift taxes. A closer comparison is between revenues from the alcohol excise tax alone and from the estate and gift taxes; the latter exceeded the former only in 1977 ( $\$ 7.4$ billion vs. $\$ 5.4$ billion) and 1980 ( $\$ 6.5$ billion vs. $\$ 5.7$ billion). $I d$.

2. See, e.g., Federal Estate and Gift Tax: Public Hearings and Panel Discussions Before the House Comm. on Ways and Means, 94th Cong., 2d Sess. 390 (1976) (statement of Edward Pendergast) (suggesting that forced sale of small businesses to meet estate tax burdens "encourage[s] people to take the 'safe' route and work for some impersonal monolithic giant") (hereinafter cited as 1976 Eslate and Gift Tax Hearings]; id. at 436-37 (statement of Sen. Gaylord Nelson) (quoting 121 CoNG. REC. 22,683 (1975)) (asserting that existing scheme of estate taxation "undermin[es] our values and institutions" and threatens "to change the historic character of our free enterprise system from reliance on independent, imaginative small businesses and family farms to absolute dependence on massive corporations"); id. at 548 (statement of Rep. Bill Archer) (equating estate taxation to "the question of the private ownership of property, whether the Government should have the power to confiscate the earnings of a citizen").

3. Sep Tax Reform Act of 1976, Pub. L. No. 94-455, §§ 2001-2010, 90 Stat. 1520, 1846-97. 
outlined a decade earlier in the American Law Institute's Estate and Gift Tax Project ${ }^{4}$ and elaborated in the 1969 Treasury Tax Reform Studies ${ }^{6}$ produced at the close of the Johnson Administration. In 1976, Congress enacted a series of provisions unifying estate and gift taxes into a wealth transfer tax with one cumulative rate schedule and one exemption level, ${ }^{\circ}$ expanding the marital deduction, ${ }^{7}$ and establishing a new tax on generation-skipping trusts. ${ }^{8}$ Through that legislation, Congress endeavored to produce a structurally more coherent tax-to move toward a genuinely progressive estate and gift tax, ${ }^{9}$ typically to be imposed once each generation without huge tax disparities due to decedents' patterns of lifetime giving. Not all of the structural problems were solved in the 1976 legislation-for example, the gift tax continues to be imposed on a net base exclusive of tax, while the estate tax applies identical rates to a gross base including the tax ${ }^{10}$-but on the whole, the 1976 changes significantly improved the structure of the estate and gift taxes.

In light of subsequent events, however, it requires emphasis that although the 1976 changes-principally the phased-in increase in the size of tax-exempt estates from $\$ 60,000$ (or $\$ 90,000$ if the lifetime gift tax exclusion was fully used) to $\$ 175,625^{11}$ and the expansion of the marital deduction for smaller estates ${ }^{12}$-were predicted to lose revenue in the short

4. American Law Institute, Federal Estate and Gift Taxation: Recommendations of the AMERICAN LAW INSTTtUTE AND Reporters' StUdies (1969).

5. U.S. Treasury Dep't, Tax Reform Studies and Proposals (1969) (joint publication of House Ways and Means Comm. \& Sen. Finance Comm. 1969) [hereinafter cited as 1969 Treasury Proposals].

6. Tax Reform Act of 1976, Pub. L. No. 94-455, § 2001, 90 Stat. 1520, 1846-48 (codified as amended at I.R.C. § 2001 (1976 \& Supp. V 1981)) (imposition and rate of estate tax) and id. § 2010, 90 Stat. at 1897 (codified as amended at I.R.C. $\S 2001$ (1976 \& Supp. V 1981)) (unified credit against estate tax); see also I.R.C. \$§ 2502, 2505 (1976 \& Supp. V 1981) (gift tax rate and credit).

7. Id. $\S 2002,90$ Stat. at 1854-55 (codified as amended at I.R.C. $\S \S 2056,2523$ (1976)); see also I.R.C. $\$ \S 2502,2505$ (1976 \& Supp. V 1981) (gift tax rate and credit).

8. Id. $\S 2006,90$ Stat. at $1879-90$ (codified as amended at I.R.C. $\$ \S 2601-2603,2611-2614$, 2621-2622 (1976 \& Supp. V 1981)).

9. See generally H.R. REP. No. 1380, 94th Cong., 2d Sess. 5 (estate and gift taxes "significantly increase progressivity" of tax system), reprinted in 1976 U.S. CODE CONG. \& AD. NEws 3356, 3359. The House Ways and Means Committee reported H.R. 14,844, a proposed Estate and Gift Tax Reform Act of 1976. Although H.R. 14,844 was not considered by the full House, many provisions of the legislation were incorporated into the conference report on the Tax Reform Act of 1976 (H.R. 10,612). 1976 U.S. Code CoNG. \& AD. NEws at 3356.

10. Compare I.R.C. $\S 2001$ (a)-(b) (Supp. V 1981) (taxable estate includes estate tax) with id. §§ 2501-2503 (value of taxable gifts excludes gift tax). Significantly greater rates are required to produce equivalent revenues on a tax-exclusive base than a tax-inclusive base. For example, a tax-inclusive rate of $40 \%$ is equivalent to a tax-exclusive rate of $67 \%, 50 \%$ is equivalent to $100 \%$, and $75 \%$ is equivalent to $300 \%$. For a discussion of tax-inclusive and tax-exclusive rates and tax bases, see INSTItute for Fiscal Studies, The Structure and Reform of Direct Taxation 28 (1978) (the "Meade Report").

11. H.R. Con. ReP. No. 1515, 94th Cong., 2d Sess. 607, reprinted in 1976 U.S. Ciode Cong. \& AD. News 4118, 4246-47.

12. Id. at 609, reprinted in 1976 U.S. Code CoNG. \& AD. News at 4248. 
run, they were to have no effect on revenue over the longer run. ${ }^{13}$ The drop in estate tax revenues in the short term from the increased exemption level and marital deduction was, in the long term, to be offset by additional revenues from the new tax on generation-skipping trusts and by application of the carryover-basis rules applicable to appreciated property transferred at death. ${ }^{14}$ In fact, the enactment of the carryover basis was an explicit trade-off for the support of the estate tax revisions by crucial Democrats on the House Ways and Means Committee. ${ }^{15}$

The 1976 revisions, of course, were not free of problems. The Senate added the estate and gift tax and carryover-basis provisions to the 1976 Tax Reform Act ${ }^{16}$ without the technical refinement that normally occurs when tax legislation moves through the Congress in the more typical manner-initial consideration in the House followed by public hearings in the Senate. ${ }^{17}$ The complexities and technical difficulties that haunted the carryover-basis provision from the outset prompted a delay in its effective date in 1978 and ultimately were a major cause of its demise in the Crude Oil Windfall Profit Tax Act of $1980{ }^{18}$ The generation-skipping provisions have met with similar technical objections, ${ }^{10}$ have faced similar delays in effective date, ${ }^{20}$ and, notwithstanding the recent Treasury proposal

13. The House report noted:

The bill is expected to reduce estate tax liabilities by $\$ 15$ million in fiscal year $1977, \$ 615$ million in $1978, \$ 803$ million in $1979, \$ 982$ million in 1980 , and $\$ 917$ million in 1981 . However, in the long run (18 to 20 years), the bill is expected to increase revenues by $\$ 273$ million per annum.

H.R. ReP. No. 1380, 94th Cong., 2d Sess. 3, reprinted in 1976 U.S. Code Cong. \& AD. News 3356, 3357. For final estimates, see H.R. CoN. REP. No. 1515, 94th Cong., 2d Sess. 626, reprinted in 1976 U.S. Code Cong. \& AD. News 4118, 4264.

14. H.R. ReP. No. 1380, 94th Cong., 2d Sess. 7, reprinted in 1976 U.S. Code Cong. \& AD. News 3356, 3360-61.

15. Estate and Gift Tax Carryover Basis and Generation-Skipping Trust Provisions and Deductibility of Foreign Convention Expenses: Hearings Before the House Ways and Means Comm., 95th Cong., 1st Sess. 182 (1977) (statement of Rep. Abner Mikva) ("[W]e sold the increase in exemption on this [carryover basis] tradeoff."). See Wall St. J., Sept. 10, 1976, at 3, col. 1.

16. H.R. Con. REP. 1515, 94th Cong., 2d Sess. 525, 607, 611-13, reprinted in 1976 U.S. CodE Cong. \& AD. News 4118, 4225, 4246, 4250-52.

17. The Senate version of the Tax Reform Act, including the gift and estate tax revisions, was adopted on August 6, 1976. 34 CoNG. Q. 2201 (1976). The conference report modified the Senate version by inclusion of some of the provisions of H.R. 14,844, a gift and estate tax bill that had been reported by the Ways and Means Committee but had not been voted upon by the full House. The conference report was adopted by both houses on Sept. 16, 1976. Id. at 2499.

18. Tax Reform Act of 1976, Pub. L. No. 94-455, § 2005, 90 Stat. 1520, 1872 (carryover basis for certain property acquired from a decedent after Dec. 31, 1979), deferred by Revenue Act of 1978, Pub. L. No. 95-600, § 515, 92 Stat. 2763, 2884 , repealed by Crude Oil Windfall Profit Tax Act of 1980, Pub. L. No. 96-223, § 401, 94 Stat. 229, 299; see Practitioner Community Writes Congress on Carryoter, 6 TAx Notes 502, 502-05 (1978); Hoffman, Drive to Repeal Carryover Basis Goes Into High Gear, 9 Tax Notes 211, 211-13 (1979).

19. Generalion-Skipping Tax Assailed by Practitioner Groups, 13 TAx Notes 1143, 1143-44 (1981) (reporting on hearings of Sen. Finance Subcomm. on Estate and Gift Taxation).

20. Economic Recovery Tax Act of 1981, Pub. L. No. 97-34, § 428, 95 Stat. 172, 319. 
for overhaul and simplification, ${ }^{21}$ may face a similar demise in the nottoo-distant future. Nevertheless, in 1976 Congress enacted major structural revisions to the taxation of gifts and bequests in an effort to have these taxes apply in a more even-handed way, without reducing the total level of deathtime taxation.

Having moved toward a basically sound and well-structured wealth transfer tax system, Congress then reversed direction a few years later and moved to emasculate it. In 1980, Congress repealed the carryover-basis rules $^{22}$ and returned to the unfair and economically distorting step-up of basis to fair market value at death. ${ }^{23}$ The tax-writing committees did not even consider enacting an income tax on appreciated assets transferred at death or the quite simple and fair proposal for an additional estate tax on appreciation, which had been developed in the 1970's by the Trust Division of the American Bankers Association. ${ }^{24}$ Then, in 1981, Congress enacted an additional increase in the wealth transfer tax credit to produce immediately a tax-exempt level of $\$ 275,625,{ }^{25}$ and phased in further credit increases to produce an exemption for all estates with net worth of $\$ 600,000$ or less. $^{28}$ At the same time, Congress extended an unlimited marital deduction to all estates regardless of size, ${ }^{27}$ reduced the top rate of estate tax-applicable only to estates with net worth of ten million dollars or more-from seventy to fifty percent, ${ }^{28}$ and increased from $\$ 3000$ to $\$ 10,000$ the amount which can annually be transferred to any donee free of gift tax. ${ }^{29}$ These changes reduce the deathtime tax base by about seventy percent and reduce the long-term revenue from taxing bequests to at most one-third of that which would have been collected if the 1976 structure had remained unchanged..$^{30}$

When the 1981 changes are fully phased in, the amount of appreciated

21. See 19 Tax Notes 551 (1983). For the attitude of the bar, see Bar Groups Urge Prompt Repeal of Generation-Skipping Tax, 20 TAx NoTEs 103 (1983).

22. Crude Oil Windfall Profit Tax Act of 1980, Pub. L. No. 96-223, § 401, 94 Stat. 229, 299.

23. See 1969 Treasury Proposals, supra note 5, at 28-29; Tax Reform, 1969: Hearings Before the House Comm. on Ways and Means, 91st Cong,, 1st Sess. 3977 (1969) (statement of Jerome Kurtz); Graetz, Taxation of Unrealized Gains at Death-An Evaluation of the Current Proposals, 59 VA. L. REv. 830, 832-38 (1973); Kurtz \& Surrey, Reform of Death and Gift Taxes: The 1969 Treasury Proposals, the Criticisms and a Rebuttal, 70 Colum. L. REv. 1365, 1381-84 (1970).

24. For a description of the additional estate tax on appreciation, see Covey, Possible Changes in the Basis Rule for Property Transferred by Gift at Death, 50 Taxes 831 (1972).

25. Economic Recovery Tax Act of 1981, Pub. L. No. 97-34, § 401(a), 95 Stat. 172, 299 (codified at I.R.C. $\S 2010$ (a) (Supp. V 1981)); [2 Estate \& Gift] Feneral TAXES (P-H) II 120,041, at 120,041 (1981).

26. Economic Recovery Tax Act of 1981, Pub. L. 97-34, § 401(a)(2)(A), 95 Stat. 172, 299 (codified at I.R.C. $\$ 2010$ (b) (Supp. V 1981)).

27. Id. § 403(a)(1), 95 Stat. at 301 (codified at I.R.C. § 2056 (1976 \& Supp. V 1981)).

28. Id. $\S 402(\mathrm{a})-(\mathrm{c}), 95$ Stat. at 300 (codified at I.R.C. $\S 2001$ (c)(1)-(2) (Supp. V 1981)).

29. Id. $\$ 441(\mathrm{a})(3)(\mathrm{b}), 95$ Stat. at 319 (codified at I.R.C. \$ 2503(b) (Supp. V 1981)).

30. Revenue losses are projected in H.R. REP. No. 215, 97th Cong., 1st Sess. 291, reprinted in 1981 U.S. Code Cong. \& AD. News 105, 379. 
property transferable at death without being subject to either income or estate taxes will have been increased ten-fold since 1976, from $\$ 60,000$ to $\$ 600,000$. With such an exemption level, no more than $\$ 3$ billion of the more than $\$ 20$ billion of unrealized appreciation annually passing through estates (at 1979 levels), or only fifteen percent, will be subject to estate tax. ${ }^{31}$ The other eighty-five percent will escape both income and estate taxation.

In 1975 , the $\$ 60,000$ estate tax exemption (which had been in effect since 1942) meant that only the wealthiest 6.5 percent of decedents paid estate tax..$^{32}$ If the $\$ 60,000$ exemption had remained unchanged, the estate tax would have applied to about the wealthiest ten percent of decedents in $1982 .^{33}$ The 1976 Act's increase to a $\$ 175,000$ exemption level ${ }^{34}$ meant that in 1981 the estate tax applied only to the wealthiest three percent of persons dying that year. ${ }^{35}$ The immediate additional $\$ 100,000$ increase, to a $\$ 275,000$ exemption level, provided by the $1981 \mathrm{Act}^{36}$ resulted in only the top one percent of 1982 decedents being subject to estate tax ${ }^{37}$ and the further phased-in increase to a $\$ 600,000$ level will exempt all but a small fraction of the wealthiest one percent of decedents from the tax. ${ }^{38}$

In summary, the 1976 legislation, which produced a more rational, more neutral, and fairer tax on gifts and bequests with no long-term reduction in revenues, was followed only five years later by legislation which made the tax all but disappear-not only in terms of the number and percentage of decedents affected, but also in terms of its contribution to federal revenues.

\section{Recent General Trends in Federal Taxation}

The schizophrenic attitude of Congress toward the estate tax, manifested by the contrast between the 1976 and 1981 legislation, reflects a fundamental tension in the tax system that has dominated tax policy de-

31. Gutman, Federal Wealth Transfer Taxes after ERTA: An Assessment 69 VA. L. REV. 1183, 1193 (1983); see infra pp. 271.

32. In 1972, the wealthiest 121,000 decedents filed returns, IRS, STATISTICS of INCOME-1972 Estate TAX RETURNS 5, 31 (1974), although there were 1.9 million decedents, 1981 StATISTICAL ABSTRACT, supra note 1 , at 71 .

33. Telephone interview with Thomas Vasquez, Deputy Director, Revenue Estimating Staff, Office of Tax Analysis, U.S. Dep't of Treasury (Apr. 15, 1983) (notes on file with author) [hereinafter cited as Vasquez interview].

34. See supra note 11.

35. Gutman, Federal Wealth Transfer Taxes After the Economic Recovery Tax Act of 1981, 35 NAT'L TAX J. 253, 253 (1982).

36. See supra note 25.

37. Vasquez interview, supra note 33.

38. Gutman, supra note 31 , at 1207. Gutman notes that "ERTA also significantly lowers the effectite rates of the transfer tax for all economic estate sizes." Id. at 1208 (emphasis in original). The effective rate of taxation declined from $6.3 \%$ to zero for economic estates of $\$ 250,000$ to $\$ 500,000$ and from $17.9 \%$ to $13.7 \%$ for economic estates of $\$ 5$ to $\$ 10$ million. See id. 
bates during recent years. Broadly speaking, the tension is one between a desire for structural tax reform, which would move the tax system towards greater horizontal and vertical equity, and a desire for tax provisions designed to stimulate increased savings or capital formation. This tension produces a direct conflict between the need to tax capital or the income from capital in order to achieve a progressive tax burden and the perceived need to exempt capital and capital income from tax in order to induce economic growth.

Comparing the tax system in 1969 with the current situation provides a useful perspective. Any such selection for an historical comparison is, of course, arbitrary, ${ }^{39}$ and my reasons for picking 1969 are not only arbitrary but also idiosyncratic. The comparison is an interesting one, however, because both the tax system itself and the political context for tax revision were quite different then.

It is best to begin with politics. Joseph Barr, the Secretary of the Treasury for fourteen days at the close of the Johnson Administration, announced that in 1966, 155 taxpayers with adjusted gross incomes of $\$ 200,000$ or more had paid no income tax. ${ }^{40}$ This announcement in January 1969 generated an extraordinary number of letters from the public to members of Congress urging tax reform. ${ }^{41}$ In 1969, most people prepared their own tax returns, and there was no such thing as a national tax shelter industry. Political leadership on tax matters resided in the House Ways and Means Committee-principally in the persons of its Chairman, Wilbur Mills, and its ranking Republican, John Byrnes, who forged "consensus" on tax revisions. Committee votes simply were not taken. ${ }^{42}$ Decisions were made in relative privacy. Committee mark-up sessions were closed, not only to the public but also to individual members' staffs. ${ }^{43}$ Virtually all of the staff work on tax matters for both the House Ways and Means and Senate Finance Committees was performed by the staff of the Joint Committee on Taxation." Amendments were generally not permitted on the House floor. ${ }^{45}$ The Ways and Means Committee bill typically became the House bill. ${ }^{46}$ There were lobbyists, to be sure, but they

39. That historical comparisons are both arbitrary and subject to manipulation to sustain a variety of positions is amply demonstrated in Bittker, Federal Estate Tax Reform: Exemplions and Rates, 57 A.B.A. J. 236, 237 (1971).

40. Treasury Chief Warns of Taxpayer Revolt, Cites $\$ 50$ Billion a Year in Preferences, Wall St. J., Jan. 20, 1969, at 4, col. 3.

41. E. Griswold \& M. Graetz, Federal Income Taxation 77 (1976); see Congress, Treasury Face Mounting Gripes from Tax Reform Advocates, Wall St. J., Feb. 19, 1969, at 1, col. 5.

42. See Graet2, Reflections on the Tax Legislative Process: Prelude to Reform, 58 VA. L. REv.

1389,1396 (1972).

43. Id.

44. Id. at $1408-09$.

45. Id. at 1397 \& n.28.

46. Id. at 1435 . 
were barred from the deliberations of the House, Senate, and Conference Committees. A "PAC" was six beers.

Turning to economics, perhaps most significant is that 1969 was the last year that the federal budget was balanced."7 The tiny surplus was accomplished with the help of a few gimmicks like accelerating withholding deposits. ${ }^{48}$ But the budget was balanced. Revenues totaled $\$ 188$ billion, principally from individual and corporate income taxes and employment taxes (see Table One). ${ }^{49}$

\section{TABLE ONE}

REVENUE SOURCES, 1969

\begin{tabular}{lcc}
\hline \hline Sector & $\begin{array}{c}\text { Amount } \\
\text { (in billions) }\end{array}$ & $\begin{array}{c}\text { Percentage of } \\
\text { Total Revenue }\end{array}$ \\
\hline Individual Income Taxes & $\$ 87.0$ & 46 \\
Corporate Income Taxes & 37.0 & 20 \\
Employment Taxes & 40.0 & 21 \\
Excise Taxes & 15.0 & 8 \\
Estate \& Gift Taxes & 3.5 & 2 \\
All Other Taxes & 5.5 & 3 \\
Total & $\$ 188.0$ & 100 \\
\hline \hline
\end{tabular}

With the exception of the extraordinary growth in employment taxes, the pattern of revenues in that year was reasonably stable compared to the past (although the total was, of course, growing). Compare, for example, ten years earlier in 1959 , when total revenue had been $\$ 79$ billion (see Table Two). ${ }^{\text {so }}$

47. 1981 Statistical AbStRact, supra note 1, at 245.

48. See 35 Fed. Reg. 19,114, 19,114-15 (1970).

49. U.S. Bureau of the Census, Statistical Abstract of the Untred States: 1971, at 245 (92d ed. 1972). Numbers may not total due to rounding.

50. U.S. Bureau of the Census, Historical Statistics of the United States 1105 (1976). Numbers may not total due to rounding. 
TABLE TWO

REVENUE SOURCES, 1959

\begin{tabular}{lcc}
\hline \hline Sector & $\begin{array}{c}\text { Amount } \\
\text { (in billions) }\end{array}$ & $\begin{array}{c}\text { Percentage of } \\
\text { Total Revenue }\end{array}$ \\
\hline Individual Income Taxes & $\$ 36.8$ & 47 \\
Corporate Income Taxes & 17.3 & 22 \\
Employment Taxes & 11.7 & 15 \\
Excise Taxes & 10.6 & 13 \\
Estate \& Gift Taxes & 1.3 & 2 \\
All Other Taxes & 1.4 & 2 \\
Total & $\$ 78.8$ & 100 \\
\hline \hline
\end{tabular}

The 1983 figures in Table Three ${ }^{51}$ reflect some significant changes. (Here I am using figures from the April 12,1983, estimate of the Office of Management and Budget; like the tides, the estimates for this year are constantly changing.)

TABLE THREE

ReVEnue SOURCES, 1983 (ESTIMATED)

\begin{tabular}{lrc}
\hline \hline Sector & $\begin{array}{c}\text { Amount } \\
\text { (in billions) }\end{array}$ & $\begin{array}{c}\text { Percentage of } \\
\text { Total Revenue }\end{array}$ \\
\hline Individual Income Taxes & $\$ 285.0$ & 48 \\
Corporate Income Taxes & 35.0 & 6 \\
Employment Taxes & 210.0 & 35 \\
Excise Taxes & 37.0 & 6 \\
Estate \& Gift Taxes & 6.1 & 1 \\
All Other Taxes & 24.9 & 4 \\
Total & $\$ 598.0$ & 100 \\
\hline \hline
\end{tabular}

51. Office of Management \& Budget, Budget of the United States Government: Fiscal Year 1984, at 9-4 (1983). 
OMB projects a total of $\$ 598$ billion in revenues. The deficit is estimated at $\$ 208$ billion $^{52}$ and is expected to be well in excess of $\$ 100$ billion for many years to come. ${ }^{53}$

With regard to sources of revenues from 1969 to 1983, the individual income tax has held relatively constant, while employment taxes have grown most dramatically. In contrast to this substantial increase in the tax burden borne by labor, tax sources generally believed to bear on capital have declined significantly. The corporate income tax has declined from an historical level of around twenty percent of total revenue to six percent and is not estimated to exceed ten percent at any time in the foreseeable future. Estate and gift taxes are also down by one-half, from two percent to one percent of total revenues. ${ }^{\text {b4 }}$

The politics of tax policy in 1983 are also quite different from those in 1969. ${ }^{.5}$ Most importantly, power has become more diffuse. There are many more players. Tax specialists have taken positions as minority and majority staff to the tax-writing committees, ${ }^{\mathrm{Bb}}$ diminishing somewhat the influence of the staff of the Joint Committee on Taxation. That Committee, which had only three persons serve as Chief of Staff in its first fifty years from 1926 to 1976, has had three different staff chiefs since 1977.87 Power has shifted away from the House Ways and Means Committee to both the House and Senate Budget Committees and to the Senate Finance Committee. Committee deliberations are now open to the public and are well attended by representatives of those groups with a special interest in the outcome. ${ }^{68}$ Political Action Committees ("PAC's"), with enormous influence over the direction of campaign funding, seem to have become similarly influential in guiding policy decisions. ${ }^{.0}$

52. Id. at 9-55. The Congressional Budget Office has more recently projected the deficit to be $\$ 190$ billion. Deficits of $\$ 190$ Billion Projected, N.Y. Times, Oct. 27, 1983, at D1, col. 3.

53. Office of MaNagement \& Budget, supra note 51, at 9-55.

54. Id. at 9-4.

55. Gutman details the political maneuvering behind the ERTA tax revisions in gift and estate taxation. He emphasizes the crucial role played in both 1976 and 1981 by the farm and small business lobbies and their congressional supporters, the competition between the Reagan administration and the House Democratic leadership to "sweeten" their respective tax packages by transfer-tax concessions to "boll weevils" and other swing-vote legislators, and the failure of proponents of the revisions to justify their proposals in terms of the underlying reasons for estate and gift taxation or the perceived deficiencies of the pre-ERTA tax scheme. See Gutman, supra note 31, at 1197-1206.

56. Reese, The Politics of Tax Reform, 32 NAT'L TAx J. 248, 248-50 (1979); Panel Discussion on the Tax Legislative Process, 32 NAT'L TAx J. 270, 273 (1979) (remarks of Edwin Cohen).

57. Telephone interview with Mike Cook, Chief Clerk, Joint Comm. on Taxation (Oct. 21, 1983) (notes on file with author).

58. See Halperin, Do Open Sessions Promote Tax Reforn?, 13 Tax Notes 3 (1981) (arguing public better served by old system of private meetings); see also Graetz, supra note 42, at 1430 (arguing against open sessions).

59. E. Drew, Politics and Money: The New Rond to Corruption 38-52, 92-93, 152 (1983) (references to tax legislation). 
Moreover, the public's attitudes towards taxation, quite positive in 1969 , have become negative in a variety of ways. A national tax-shelter industry-often operating without adequate basis in either law or fact-has blossomed like a hundred roses. ${ }^{60}$ Not counting revenues lost from "abusive tax shelters," there is now a "compliance gap" of approximately $\$ 75-\$ 100$ billion of taxes due but not reported. ${ }^{61}$ Apparently many high-income taxpayers now participate in tax shelters, while many middle-income taxpayers achieve their tax reductions by cash transactions and tax fraud. Virtually no one prepares his or her own tax return anymore. The public no longer urges that the tax system be made more fair. Jimmy Carter's favorite target, the deduction for business meals, which he labeled the "three-martini lunch," evoked a response only from the nation's restaurants and restaurant employees. ${ }^{62}$ A massive letter-writing campaign-one of the largest in the nation's history-recently urged repeal of witholding on dividends and interest, ${ }^{\text {ss }}$ but this deluge was apparently stimulated by the banking and thrift industries. ${ }^{e 4}$ Public-opinion polls invariably reflect a public taste for a fairer tax system, but if that taste reflects concern other than a lowering of each individual's own taxes, it seems politically impotent.

This 1969-1983 comparison suggests several trends. First, the dominant economic factor influencing tax policy today is the projection of very large current and future deficits. ${ }^{65}$ If spending is-as seems to be the case-not likely to be reduced further in substantial amounts, the deficit can be narrowed only by additional revenues. Economic recovery may partially close the revenue gap, but, as state and local governments are learning, increased and new taxes will undoubtedly prove necessary. ${ }^{88}$ This need for revenues, however, is constrained by great reluctance, by both this Administration and important members of Congress, to increase the tax burden on capital or capital income for fear of stifling economic growth. ${ }^{87}$ In con-

60. See, e.g., Gyps, Busts and Squirrels Plague the IRS, Washington Post, Apr. 15, 1982, at A23, col. 3 (noting increase in evasion, avoidance, delinquency, and abusive sheltering of taxes); ' $A b u$ sive' Tax-Shelter Plans Cost the U.S. \$3 Billion Annually, IRS Chief Estimates, Wall St. J., Sept. 29, 1982 , at 2, col. 3 (discussing increased marketing of abusive tax shelters).

61. See Gyps, Busts and Squirrels Plague the IRS, Washington Post, Apr. 15, 1982, at A-23, col. 3. In addition, the federal government is owed over $\$ 5.5$ billion in delinquent taxes. Id.

62. See Don't Tax You, Don't Tax Me . . ., Washington Post, Mar. 24, 1978, at B-7, col. 1.

63. See Senate Backers of Interest Withholding Accept Compromise That Could Kill Bill, Wall St. J., Apr. 20, 1983, at 2, col. 3.

64. Id.

65. See supra p. 266.

66. See Manvel, Trends in State Tax Yields, 19 TAx Notes 1004, 1004-06 (1983).

67. See generally President's Remarks to AFL-CIO National Legislative Conference, 18 WEEKLY Comp. Pres. Doc. 444, 449 (Apr. 5, 1982) (observing, in urging opposition to elimination of third year of tax cut, that higher taxes reduce savings and work incentives, and hence produce weaker economy); Bradley Would Set Top Tax Rate at 30 Percent, 19 TAx Notes 1008 (1983) (reprint of press release from Sen. Bradley stating that his "Fair Tax Act" would eliminate "Ioopholes" to lower 
trast, fairness in the distribution of the tax burden seems of little political significance since it currently enjoys no meaningful constituency.

\section{The Role of the Estate Tax}

These conditions combine to make the estate tax a very minor player indeed. Since it is a tax on savings, proposals to increase the estate tax run headlong into concerns over "capital formation." Moreover, the estate tax has very limited potential as a source of federal revenues. Although the estate tax accounted for nearly eleven percent of federal revenues at its zenith in 1936 , $^{\text {e8 }}$ estate and gift taxes have never produced more than two and one-half percent of total revenue since the end of the Second World War. ${ }^{88}$ Even if the most recent trends were reversed by returning to the pre-1976 tax-exempt level of $\$ 60,000$ instead of proceeding with the phased-in increases to a $\$ 600,000$ tax-exempt level, estate taxes would only be double their current total and would again produce only about two percent of total revenue. ${ }^{70}$ If the estate tax were increased still further to produce a post-war high of two and one-half percent of total revenue, it would generate only an additional $\$ 8$ billion, an amount which would make only a very small dent in the projected federal deficits. ${ }^{71}$

The limitation on potential estate tax revenues is an inherent one, not merely a product of political obstacles. Decedents annually transfer a total of about $\$ 120$ billion in net assets. ${ }^{22}$ An average effective tax rate of twenty percent would produce total revenues of about $\$ 24$ billion, approximately three times the current level. With any substantial exemption, plus exclusions for certain amounts of property passing to surviving spouses or charities, a higher average effective rate seems unrealistic. The inherent limitation on bequests as a source of revenue cannot be overcome by even a dramatic structural revision of estate and gift taxes, such as converting to an inheritance or accessions tax, or taxing gifts and bequests as income to the recipient (or, in a consumption tax world, as consump-

tax rates to "encourag[e] the work and investment that we need for long-term economic growth").

68. Eisenstein, The Rise and Decline of the Estate Tax, 11 TAX L. REv. 223, 239 (1956), reprinted in Readings in Death and Gift Tax Reform 3, 19 (G. Goldstein ed. 1971).

69. 1981 Statistical. AbSTRACT, supra note 1, at 256; 1961 Statistical AbStract, supra note 50 , at 372 .

70. Vasquez interview, supra note 33.

71. In 1981 , total federal revenue was $\$ 606.8$ billion. U.S. BuREau of The Gensus, StatistiCal Abstract of the UNITEd States: 1982-83, at 254 (103d ed. 1982) thereinafter cited as 198283 Statistical ABSTRACT]. Thus, 2.5 percent of total federal tax revenue was approximately $\$ 15.2$ billion. In 1981, estate and gift taxes generated only $\$ 6.9$ billion in revenue. Id. In comparison, a one percentage point increase in the federal income tax rate would raise more revenue than does the present estate and gift tax. See Gutman, supra note 31, at 1189 n.10.

72. See R. Musgrave \& P. Musgrave, Public Finance in Theory and Practice 502 (3d ed. 1980). 
tion of the donor). A tax on deathtime transfers of wealth will thus not serve as a major source of federal revenues.

So we must look elsewhere than the production of revenues if we are to justify strengthening, rather than eliminating, the estate tax. That place should be its role in the distribution of the tax burden, in particular, its role in providing an important element of progressivity in the federal tax system.

Other than the dramatic increases in total revenues, the most striking characteristic of changes in the federal revenue sources described above is the diminishing relative significance of progressive tax sources. Viewed as a system of purchasing retirement and disability insurance from the government, the huge rise in employment taxes reflects a dramatic increase in taxes grounded in notions of "benefit" rather than "ability to pay." By contrast, if current employment taxes are considered to be taxes on the current generation of workers to fund the current retirement benefits of predecessor generations, rather than insurance purchased by current workers-a view that may well reflect the views of current workers-a far greater share of federal tax is imposed on labor income than in the past. In addition, employment tax ceilings on taxable labor income exempt a portion of the wages of highly salaried individuals. ${ }^{73}$ The employment tax increases, ${ }^{74}$ in combination with recent cutbacks in the top rates of individual income taxes $\mathrm{s}^{75}$ and reductions in estate ${ }^{76}$ and corporate income and capital gains taxes, ${ }^{77}$ pose significant threats to the progressivity of federal taxation.

Moreover, the proposals for significant long-term changes in federal taxation that currently enjoy the greatest favor in both academic and political circles-a flat-rate tax and a consumption tax-pose further threats to progressivity. ${ }^{78}$ The Treasury has estimated that a flat-rate tax would shift approximately $\$ 32$ billion of taxes from upper-income (individuals with more than $\$ 50,000$ income) to lower- and middle-income taxpayers. ${ }^{79}$ Replacing all or part of the income tax with a consumption tax-which would probably be a value added or retail sales tax-would exempt savings completely from the tax base and would likely increase the

73. For example, in 1983 , all income in excess of $\$ 35,700$ was exempt from Federal Insurance Contribution Act [Social Security] taxes. See 47 Fed. Reg. 51,003 (1982) (announcing Social Security contribution and benefit base for remuneration paid in 1983).

74. Social Security Amendments of 1977, Pub. L. No. 95-216, § 101, 91 Stat. 1509, 1510-12.

75. Economic Recovery Tax Act of 1981, Pub. L. No. 97-34, $\S 101,95$ Stat. 172, 176-85.

76. Id. $\$ \S 401-403,95$ Stat. at 299-305.

77. Id. $\S 231,95$ Stat. at 249-50; Revenue Act of 1978, Pub. L. No. 95-600, $\S 301,92$ Stat. 2763, 2820-24.

78. See Graetz, The 1982 Minimun Tax Amendments as a First Step in the Transition to a "Flat-Rate" Tax, 56 S. CAL. L. Rev. 527, 532-33 (1983).

79. Id. at 533 (citing testimony by John Chapoton, Ass't Treasury Sec'y for Tax Policy). 
burden on low- and middle-income taxpayers while reducing that on upper-income taxpayers. ${ }^{80}$

To view the estate tax, however, as contributing an important element of progressivity to the federal tax system requires shedding a myth which has come to dominate its political discussion. This myth-repeated most recently in the legislative history of the 1981 Act-is that the proper function of the estate tax (as well as its historical role) is only to "break up large concentrations of wealth." 81 The clear implication-indeed, the principal justification for raising the tax-exempt level of estates to $\$ 600,000$-is that no estate tax should be imposed on "smaller or moderate-sized estates."82 In 1981, "smaller and moderate-sized estates" meant those of the wealthiest one to six percent. ${ }^{83}$ If the 1976 tax-exempt level of $\$ 60,000$ had been maintained, the estate tax would now apply to the wealthiest ten percent of decedents. ${ }^{84}$ The narrowing of the estate tax base that accompanies political acceptance of this myth necessarily defeats the contribution of this tax to the progressivity of the federal tax system. The tax becomes as narrow in its intended function as it is in its contribution to the government's revenue. A strong case can then be advanced for its elimination altogether.

In fact, however, the estate tax has done very little to dilute the greatest concentrations of wealth. The portion of total wealth held by the richest one percent of wealth-holders has remained remarkably stable. ${ }^{85}$ They possessed roughly one-fourth of the national wealth in every year from 1958 to $1972 .^{86}$ A recent study advances a tentative estimate that their holdings declined from one-fourth to about one-fifth of total wealth between 1972 and $1976 .{ }^{87}$ Even assuming that such a decline has actually occurred, however, nothing suggests any significant causal role for the estate tax.

Looking instead at the contribution of the estate tax to the progressivity of the tax system reveals a quite different picture: It has had a significant

80. McLure, The Value Added Tax: Effects on Productivity and Equity, 20 TAx Notes 971, 976 (1983) ("replacing part of [the personal or corporate income tax] with a VAT would substantially reduce the progressivity of the tax system"); sep also Goode, The Superiority of the Income Tax, in What Should Be TaXed: Income or Expenditure? 49, 56 (J. Pechman ed. 1980) (asserting that expenditure tax would have to have more steeply graduated rates to achieve progressivity achieved by income tax).

81. See S. Rep. No. 144, 97th Cong., 1st Sess. 124, reprinled in 1981 U.S. Code Cong. \& AD. NEws 105, 226.

82. See id.

83. Sep Gutman, supra note 31 , at 1193.

84. Vasquez interview, supra note 33.

85. 1976 Estate and Gift Tax Hearings, supra note 2, at 1311, 1315 (statement of James Smith).

86. Id. at 1317 (Table 3).

87. J. Smith, Trends in the Concentration of Personal Wealth in the United States (Draft Paper for Meeting of the Int'l Assoc. for Research on Income and Wealth, Aug. 1981). 
progressive effect. In 1970, the average ratio of tax to adjusted gross income on individual income tax returns was 13.7 percent. $^{88}$ Those taxpayers who were taxed at an average rate of at least 14 percent paid a total tax of $\$ 43$ billion. ${ }^{89}$ If they had paid their tax at the average rate, the government would have received only $\$ 30.5$ billion. $^{90}$ The total revenue raised through individual income taxes in excess of the average rate was therefore $\$ 12.5$ billion. By comparison, the fiscal year 1970 estate and gift tax collections from upper-income decedents were just under $\$ 3.7$ billion.91 Thus, the estate and gift taxes-despite their low revenue yield-contributed nearly one-third as much to the progressivity of our tax structure as did rates in excess of the average individual income tax even though the estate tax imposed a smaller levy on inheritances than would have been imposed if bequests had been taxed as ordinary income.

A similar calculation for 1972 confirms this impact. Again, the estate and gift taxes contributed nearly one-third as much to the progressivity of our tax structure as did progressive individual income rates. ${ }^{92}$ Data for the most recent year available, however, reveal a different picture. The average income tax rate had not changed greatly ${ }^{93}$ but the revenue raised by the estate tax amounted to only about twelve percent of that raised by income tax rates greater than the average ${ }^{04}-\mathrm{a}$ far smaller contribution to progressivity than before. With the further increases in the estate tax marital deduction and tax-exemption enacted in 1981, the relative importance of the estate tax will decline even further. Professor Harry Gutman has estimated that if the estate tax changes of the 1981 legislation were fully effective in 1981, "the contribution to progressivity [of the estate tax] would be reduced to approximately 4 percent."'95 Whatever progressivity

88. 1981 StATISTICAl. ABSTRACT, supra note 1, at 257.

89. See IRS, Statistics of Income-1970 Individual Income Tax Returns 180 (Table 59) (1972). This figure was obtained by first dividing the figures in column 15 (total income tax paid) by the figures in column 2 (adjusted gross income). (Column 15 divided by column 2 represents the percentage of adjusted gross income paid as income tax.) The sum of the figures in column 15 for each cohort whose tax rate exceeded 14 percent equals the amount of tax paid by persons whose tax rate exceeded the average rate.

90. Sep id. This figure was obtained by summing the amounts in column 2 for those cohorts which were taxed at an above-average rate and multiplying the total by the average tax rate.

91. U.S. Bureau of the Census, Statistical austract of the UnIted States: 1972, at 389 (93d ed. 1972).

92. 1976 Estale and Gift Tax Hearings, supra note 2, at 1237 (statement of Michael Graetz).

93. In 1980, the percentage of adjusted gross income paid in income tax was 15.5\%. 1982-83 Statistical ABSTRACT, supra note 71, at 255.

94. Gutman, supra note 35 , at 261-62.

95. Id. at 262. Professor Gutman contends that the Graetz and Treasury methodologies do not provide "a precise measure of the annual contribution of the transfer taxes to progressivity," id. at 262 , because annual transfer-tax receipts are only "a proxy for aggregate annual individual accruals to discharge future transfer tax liabilities," id. at 267 n.42. He suggests that progressivity would be more accurately measured by comparing income and employment taxes paid by an individual today with the present value of the estate tax to be paid by the same individual tomorrow. 
remains in the federal tax system will be supplied entirely by the income $\operatorname{tax}$.

Reliance on progressive income tax rates as the sole mechanism for ensuring that this nation's tax burden is distributed in accordance with ability to pay poses a number of problems. Realized rates of return apparently tend to fall as wealth increases. Thus, any tax system which relies solely on an income tax to attain progressivity will not sufficiently tax the underlying wealth that generated the income. ${ }^{96}$ High income tax rates both create marginal disincentives to productivity and stimulate legal and illegal noncompliance. ${ }^{97}$ Moreover, many preference provisions that have long been a part of the income tax exempt certain sources of income from capital. ${ }^{83}$ And although the aggregate contribution of the individual income tax to federal revenues has been relatively stable over time, recent revisions of the income tax base have further tended to exclude income from capital. Among the most significant of these were the 1978 expansion of the capital gains exclusion, ${ }^{89}$ the 1980 repeal of deathtime carryover basis rules, ${ }^{100}$ the 1981 reductions in the top rate of tax on dividends and interest income from seventy to fifty percent, ${ }^{101}$ and increases in depreciation allowances and tax-free retirement accounts. ${ }^{102}$

The principal reason, therefore, to revise the estate tax is to rescue this mechanism for achieving progressivity, and perhaps to rescue progressivity itself, from both short- and long-term threats. Deciding that restoration rather than repeal is the appropriate course requires three steps: (1) a judgment that progressivity in taxation is just and therefore good; (2) a view that the estate tax can and should play an important role in achieving progressivity; and (3) a conclusion that progressivity should not be abandoned because of the adverse impact of progressive taxation in general (and the estate tax in particular) on capital formation. I shall now turn to an examination of these three propositions.

96. See C. Steuerle, The Relationship Between Realized Income and Wealth: Report from a Select Sample of Estates Containing Farms or Businesses 2-4, 17 (Office of Tax Analysis, U.S. Dep't of the Treasury, OTA Paper 50, Dec. 1982) (permission to cite obtained by author).

97. See supra note 60 .

98. See, e.g., I.R.C. $\S 103$ (1976 \& Supp. V 1981) (exemption of interest on state and local bonds); id. $\S 617$ (mining depletion allowances); id. $\S 1202$ (capital gains deduction).

99. Revenue Act of 1978, Pub. L. No. 95-600, § 402, 92 Stat. 2763, 2867-68 (codified at I.R.C. § 1202 (Supp. V. 1981)).

100. Crude Oil Windfall Profit Tax Act of 1980, Pub. L. No. 96-223, § 401, 94 Stat. 229, 299.

101. Economic Recovery Tax Act of 1981, Pub. L. No. 97-34, § 101, 95 Stat. 172, 176-85 (codified at I.R.C. $\S 1$ (Supp. V 1981)).

102. Id. $\S 201,95$ Stat. at 203-19 (codified at I.R.C. $\S 168$ (Supp. V 1981)) (accelerated cost recovery system); $i d$. $\S \S 311-312$, 95 Stat. at $274-85$ (codified at I.R.C. $\S 219$ (Supp. V 1981)) (retirement savings provisions). 


\section{In Defense of Progressivity}

I shall not attempt here a full-blown defense of progressive taxation. Nearly thirty years ago, Walter Blum and Harry Kalven spent more than one hundred pages demonstrating that the case for progressive taxation is uneasy. ${ }^{103}$ But, with similar scrutiny, the case for proportional taxation should prove at least equally uneasy, and the case for regressive taxation is surely wrong. ${ }^{104}$

All I want to do here is to call into question the analytical starting point of virtually all of the detractors of progressive taxation. Each of them-including Blum and Kalven - begins with the presumption that the earnings of suppliers of both capital and labor in a market economy are appropriate not only as a necessary concession to economic efficiency or to making a market economy work, but also "morally" appropriate as rewards to the owner of capital or the laborer. This view is grounded in a widely shared belief that returns to capital and labor reward personal merit, industriousness, and productivity. In this view, the market rewards the strong and the deserving and fails to reward only the lazy, weak, or otherwise undeserving. Since income and wealth are regarded as manifestations of merit, people can see little reason for taxing such income or wealth in order to fund government spending on public goods or redistribution to others. From such a starting point, it becomes necessary to "make a case" for progressive taxation, indeed for any taxation at all, and the debate quickly turns into a series of unconvincing "ethicalaesthetic"10s assertions about the "proper" or "fair" distributions of income or wealth for society-assertions which cannot promise widespread agreement in a heterogeneous society.

The nature of the argument is effectively predetermined by the assumption that the market distribution is "ethical" or "just." A move away from the results of the marketplace necessarily becomes "uneasy," and proponents of any such move are burdened with the requirement of demonstrating that their taxation scheme is also "just."

103. W. Blum \& H. Kalven, The Uneasy Case for Progressive Taxation (1953). Prof. Blum, in a five-page retrospective, concluded, "In the early 1950s the case for progressive taxation was not easy. Subsequent developments in our society have made it no less, and perhaps even more, uneasy." Blum, Revisiting the Uneasy Case for Progressive Taxation, 60 TAxes 16, 21 (1982).

104. I have advanced these arguments regarding progressive taxation elsewhere. See Graetz, Commentay, in WeAlth Redistribution AND THE Income TAX 45-56 (A. Leibowitz ed. 1978); see also Sen, Just Desserts, N.Y. REv. Books, Mar. 4, 1982, at 3, 3-6 (Book Review) (defending egalitarian policies favoring wealth redistribution). It is Boris Bittker's view that "the case for progressive taxation is 'uneasy,' but it seems no more uneasy than the case for proportionality or for preferring one tax base over another." C. Galvin \& B. Brtrker, The Income TAX: How Progressive SHOULD IT BE? 58 (1969).

105. See H. Simons, Personal. Income Taxation 18-19 (1938) (characterizing such arguments as "ethical-aesthetic"). 
But that starting point is highly questionable. It is very difficult to justify the market's distribution as ethical. The justification for a marketdetermined distribution of income and wealth must rely on economic efficiency and consumer and producer sovereignty - a belief that a market economy avoids waste and increases the standard of living even for those with a lesser distributional share, coupled with the view that minimal governmental interference in the market increases freedom of choice and liberty generally. Some would even argue that any adjustment to the distribution of the market is contrary to the basic decision to maintain a system of private property. These concerns-for output, retention of a private property system, and consumer and producer sovereignty-necessarily require inequality in the distribution of income and wealth, which means that equality of result cannot be an appropriate target for governmental policies, but they do not prohibit a redistributional policy to reduce market-induced inequalities.

There are several reasons not to regard market distributions as inherently fair or as presumptively just. First, even when the market is functioning perfectly, returns to both capital and labor inputs depend upon the demand for the product or service being produced. The rewards the market place bestows depend on factors outside an individual's control. In a market economy, people who supply capital or labor to industries or endeavors where demand for the product or service proves strong will do very well; people who work or risk their capital in industries or endeavors where market demand for the product or service proves weak will do quite badly. The enormous demand by customers for Olivia Newton-John to sing "Let's Get Physical"106 has made her a very wealthy woman. If public tastes were to improve and demand for her services were to decrease, her income would decline dramatically without regard to any change in her ability or work effort. The most recent recession significantly injured American workers in the automobile industry, because demand for American automobiles was very weak. The person who made the first hula hoop became rich while the person who made the last one probably became poor. Barbers did better in the early 1950's than in the late 1960's.

Second, even in a perfectly functioning market economy, most production is based upon the joint use of different resources, typically provided by different people. In such circumstances, it is usually impossible, as an

106. O. Newton-John, Physical, on Physical side 2, track 1 (1981), re-released on 2 Olivia's Greatest Hits side 1, track 3 (1982); hear also Captain \& TEnille, Muskrat Lotie, on Captain and Tenille's Greatest Hits side 2, track 1 (1977); B. Manilow, I Wrile the Songs, on Tryin' To Get the Feeling side 2, track 1 (1978). 
ethical matter, to determine which person-or even which resource-produces or deserves what share of the total output.

Third, some share of total market returns to capital and labor are attributable to societal conditions. The existence of public institutions, including laws and law enforcement mechanisms-criminal and corporate codes and courts to enforce them, for example-affects returns to private institutions and individuals. As attorneys, we have been fortunate that the American demand for legal services has been remarkably robust. Even where that demand was from consumer preference rather than caused by governmental action, attorneys have not become wealthy because of the social worth of their services. The comparatively low earnings of lawyers in other nations cannot fairly be attributed to a failure of individual "aptitudes and motivations for economic achievement,"107 but rather are due to particular societal conditions and protections. ${ }^{108}$ In this light, it might well make sense to ask what portion of output and of returns to labor and capital should be characterized as societal rather than individual creations.

Fourth, returns to capital and labor are dramatically affected by luck, by good rather than ill fortune. Many outcomes are determined simply by accidents of birth-being born in this country rather than in the Third World; being born smart or good-looking, rather than stupid or ugly; being born into a family of wealth and education, rather than one of poverty and ignorance. The empirical evidence shows that inherited wealth accounts for at least half the net worth of wealthy men and for most of the net worth of wealthy women. ${ }^{109}$ Enormous one-shot gains explain most of the remainder of the significant wealth advantages of the truly rich.110 The huge gains enjoyed by people who owned oil in the mid-seventies were not in any sense ethically deserved, nor are the advantages of inherited wealth. Both of these sources of great wealth are typically "morally arbitrary."

This litany is intended only to call into question the typical starting point of people who attack the moral validity of progressive taxation, of those who simply assume that the market distributes rewards to people who deserve them and denies rewards to people who do not. The problems raised here call into question the ethical justification for the distributions of income and wealth in a perfectly functioning market economy.

107. Sen, supra note 104, at 5 (quoting P. BaUer, EQUALITY, THE THIRd WORLd AND EcoNOMiC DeLuSION (1981)).

108. See Graetz, supra note 104, at 47.

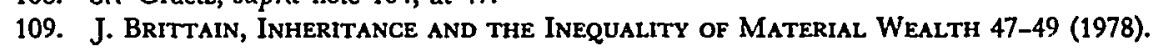

110. Id. at 72 . 
When the market functions imperfectly, as it always does-where the economy is burdened by inflation or unemployment or both; where industry is organized to produce monopoly benefits, perhaps through legal barriers to entry; where political influence or patronage produces private advantages; where equality of opportunity is absent-neven the most modest ethical claims for the justice of a market distribution of income and wealth are further weakened. One need not believe that the rewards of personal dedication and integrity are nil, or that the lazy and inefficient do better than the industrious and efficient, to conclude that little of what we own is truly attributable to individual merit alone. All receipts are joint products, both individual and societal. Because individual characteristics and social characteristics are both essential to their joint outcome, there is simply no means by which a percentage of individual and social "dessert" can be calculated.

Thus, the justification for a market distribution must ultimately be grounded in concerns about total output-economic efficiency rather than ethics-and in concessions to certain liberties. Before turning to the economic efficiency issue, let me briefly identify the liberties that I regard as directly affected by any change in the market's distribution of income and wealth through taxation.

Four separate liberties seem to be involved. ${ }^{111}$ The first is the liberty of consumer sovereignty: purchasers' right to buy Olivia Newton-John's awful records if they wish. The second is the liberty of producer sovereignty: Ms. Newton-John's right to refuse to perform her songs in light of the amount she would be able to retain after taxes. These two are very important liberties but they are not constrained by progressivity in taxation. The third liberty, her liberty to keep all that is paid by the consumer to purchase her songs, and the fourth liberty, that of her heirs to be able to keep whatever of the consumer's payments she does not consume before death, are not nearly so absolute. There is, I think, very little justification for protecting the rights of her lineal descendants to enjoy an enormous advantage over others, an advantage which in this case resulted from the tastes of the American consumer in the 1980's. I do not know why that liberty should be protected-and in considering estate taxation, it is, after all, heirs' interests which are at stake. Moreover, there are also important conflicting liberties at stake here, most significantly the liberty interests of lineal descendants of other people to start off with a rough equality of opportunity and of initial wealth.

Even this brief review of the liberty interests at stake reveals that mod-

111. In identifying these liberty interests as the relevant ones, I am following Scanlon, Nozick on Rights, Liberty, and Property, 6 PHIL. \& PuB. Aff. 3, 7 (1976). 
ern philosophers, such as the widely read and cited Robert Nozick, ${ }^{112}$ who argue that progressive taxation of income is the equivalent of compulsory servitude, ${ }^{118}$ engage in an unconvincing form of reductionism that fails to make distinctions which most tax lawyers would regard as relevant.

The case for progressive taxation becomes far easier when one rejects the strong presumption that the market distribution of income and wealth is necessarily linked to fairness or freedom. This may well explain why in 1976 even the conservative William Simon, when he was Secretary of the Treasury in the Ford Administration, could assert: "There appears to be widespread consensus that an element of progression is desirable in the tax structure."114 Progressivity in taxation will not lead the United States inexorably to become-as some would have us believe-a "provincialized backwoods, with a decaying obsolete technology, where all privacy and individuality will be abolished and a person might be beheaded for demonstrating a modicum of intellectual or entrepreneurial independence."115 There is quite a strong case to be made for the fairness of substantial and progressive taxes on bequests, unless, of course, there is an instrumentalist barrier to such taxes-a barrier due to the impact of such taxes on economic production and output, a barrier resulting from an adverse impact of such taxes on economic growth. I shall now turn to that question.

\section{Capital Formation Is Not the Trump}

I want now to consider what I regard as the most important objection to estate taxation, indeed to taxation of wealth or capital income in any form. This, of course, is the adverse impact of such taxes on the amount of savings and investment, that is, on capital formation.

The basic argument is quite straightforward. Our nation needs more savings if it is to enjoy economic growth. The estate tax is levied on savings, and taxing such savings will cause people to save less. The argument, of course, implicates all progressive taxation if the marginal propensity of higher-income individuals to save exceeds that of low-income individuals. Although the argument is sometimes expressed in terms of an equity-efficiency tradeoff, ${ }^{118}$ taxes on capital are often analyzed only in

112. R. Nozick, ANarchy, State, and Utopia (1974).

113. Id. at $169-70$.

114. Treas. Doc. 76-25 (Sec'y of Treasury William Simon's letter to Mrs. Llewellyn Lowe), reprinted in TAX Notes Dec. 27, 1976, at 11.

115. Both my research and that of the Journal have failed to uncover the source of this quotation. I am offering a tax book to the first person who can correctly identify the source of this quotation. I am here following the example of Boris Bittker, who once made a similar offer when he was unable to find the source of a quotation in one of his writings. [Professor Bittker has also promised a tax book to the first person who can identify the footnote in which his offer was made. Responses should be directed to the offerors.-Ed.]

116. Sep, e.g., A. Okun, Equality and Efficiency: The Big Tradeoff 88-120 (1975) (dis- 
terms of their effects on economic growth and efficiency. ${ }^{117}$ The case for lower taxes on capital, however, is far from clear.

At the outset, one might question the alleged need for increased savings. There is considerable evidence that the savings rate has not declined since the 1930's and that there now exist large amounts of excess industrial capacity. As a recent Federal Reserve study observed: "From the standpoint of gross total investment as a share of total economic activity, there is no evidence of a declining rate of U.S. capital formation."118 Similarly, gross total savings and gross private savings have been essentially without trend. ${ }^{110}$ The data show cyclical volatility, and that, subsequent to the enactment of the investment tax credit in 1962, there has been a shift of business investment from structures to equipment. ${ }^{120}$ Second, while efforts to measure the contribution of capital to economic growth are controversial within the economic profession, empirical findings suggest that technological advances and population growth, rather than increases in savings, have accounted for the bulk of economic growth. ${ }^{121}$ Even the current economic recovery seems to be led by demand-side spending rather than supply-side saving. ${ }^{122}$ But let us put such questions aside and assume that the country needs more savings. What would that imply for the estate $\operatorname{tax}$ ?

The estate tax is such a small revenue source that its effects on savings and investment are no doubt dwarfed by the impact of other taxes and by fiscal and monetary policies. Perhaps for this reason, the impact of the estate tax on aggregate savings has not received much explicit theoretical or empirical examination by modern economists. The modern economic

cussing equity-efficiency tradeoff in context of transfer payments to poor); Sandmo, Optimal Taxation: An Intraduction to the Literature, 6 J. PUB. Econ. 37 (1976) (discussing optimal tax rates from perspectives of income distribution, work incentives, and capital formation).

117. Current \& Quolable: Ture on New Directions in Economic Policy, 17 TAx Notes 1289, 1291; Ture, The Economic Effects of Tax Changes: A Neoclassical Analysis, in JoInT Economic Committee, 4 Special Study in Economic Ghange: Stagflation-The Causes, Effects, AND Solutions 316, 343-45 (1981).

118. Enzler, Conrad \& Johnson, Introduction and Suminary, in Fed. Reserve Sys., Public Policy and Capital Formation 1, 5 (1981); see Johnson, Capital Formation in the United States: The Postu'ar Perspectite, in Fed. Reserve Sys., supra, at 47, 57.

119. Enzler, Conrad \& Johnson, supra note 118, at 5; see H. AAron, ECONOMIC EFfects of SOCIAL SECURITY $31 \mathrm{n.4}$ (1982) (noting that average net private saving rate was $7.96 \%$ from 1948 to 1964 and $8.22 \%$ from 1965 to 1980 ).

120. Auerbach, Taxation, Corporate Financial Policy and the Cost of Capital, $21 \mathrm{~J}$. Econ. LiTERATURE 905, 929 (1983); Enzler, Conrad \& Johnson, supra note 118, at 5; Johnson, supra note 118 , at 55 .

121. Enzler, Conrad \& Johnson, supra note 118, at 7-9, 11; Lubitz, Capital Formation and Satings in Major Industrialized Countries, in FED. RESERVE SxS., supra note 118, at 59, 68-69.

122. Americans Saving Less Now Than Before the ' 81 Tax Act, N.Y. Times, Sept. 6, 1983, at A1, col. 2, D7, col. 1 (reporting that consumer spending jumped $9.7 \%$ in second quarter of 1983 , "accelerat[ing] the economy's recovery from the recession to a rollicksome, 9.2 percent pace"). 
literature does, however, contain observations by Richard Musgrave, ${ }^{123}$ Lester Thurow, ${ }^{124}$ and Gerard Brannon ${ }^{125}$ that deathtime taxes on capital, such as estate taxes, are likely to have smaller disincentive effects than lifetime income taxes.

Unfortunately, given results to date of much more extensive economic research on related issues, I do not expect that more detailed investigation of the estate tax by professional economists will produce unambiguous results. For example, public finance economists have devoted great attention recently to the effects of taxation on incentives to invest, with particular emphasis on efforts to discover the effects of corporate (and related personal) income tax rules on business investment decisions. ${ }^{126}$ They have observed many distortions, most notably how the deductibility of interest has biased financing decisions and how depreciation rules have created great differentials in effective corporate tax rates across investments. ${ }^{127}$ Conclusions about the overall impact of corporate and personal income taxes on business investment decisions, however, are harder to come by. An exhaustive review of the recent economic literature offers the following summary of the results:

[T] hough we have learned much in recent years about how taxes might motivate the behavior of [corporate] managers, we have yet to develop a unified theory capable of explaining fully the dividend, leverage and investment decisions that managers make. Nor have we been able to answer without ambiguity, questions about the empirical importance of the effects of different taxes and inflation on the cost of capital. Greative empirical approaches and richer models of behavior may be necessary for future insights to be gained. ${ }^{128}$

At a more impressionistic level, there is the revealing response of Norman B. Ture, who was Undersecretary of the Treasury for Tax and Economic Affairs and is often described as an architect of the 1981 tax legislation. When confronted with the fact that personal savings declined to a 33-year low following that legislation, he replied: "It is not only a dis-

123. Sep R. Musgrave, Theory of Public Finance 248 (1959).

124. See L. Thurow, The Impact of Taxes on the American Economy 157-58 (1971).

125. See Brannon, Death Taxes in a Structure of Progressize Taxes, 26 NAT'L TAx J. 451, 451-52 (1973).

126. For an excellent discussion of the recent literature, see Auerbach, supra note 120; see also A. auerbach, The Taxation of Capital Income (1983); M. Feldstein, Capital Taxation (1983); Kopcke, The Efficiency of Traditional Investinent Tax Incentives, in FEd. Reserve Sys., supra note 118 , at $163-75$.

127. See, e.g., Jorgenson \& Sullivan, Inflation and Corporate Capital Recovery, in Depreciation, Inflation, and the Taxation of Income from Capital 171, 195-210 (C. Hulton ed. 1981); Auerbach, supra note 120, at 912-17.

128. Auerbach, supra note 120 , at $936-37$. 
turbing result. It's very surprising." ${ }^{\text {229 }}$ Since educated guessing is clearly appropriate, I offer my suspicion that tax-induced distortions in specific financing and investment decisions may have a far greater deleterious impact on economic activity than any disincentive effects due simply to the existence of corporate and personal income and estate taxation.

A second major endeavor of public finance economists in the last decade has been to study the increasingly significant impact of Social Security employment taxes and retirement benefits on aggregate savings. Massive amounts of theoretical and empirical research have been completed and "reputable economists may be found who argue that Social Security has decreased savings, increased savings, or had no perceptible effect."130 Moreover, the uncertainties surrounding the Social Security debate relate directly to the estate tax question because they center on what Henry Aaron describes as one of "the key unresolved analytical issues in economics, the question of how long a planning horizon individuals have ...."131 At the most fundamental theoretical level in the analysis of individuals' savings behavior, three models compete. ${ }^{132}$ Two of the theoretical models used to analyze Social Security-the more frequently used "life-cycle hypothesis"133 and the "short-horizon model"134_imply that estate taxes should have little or no effect on savings, ${ }^{136}$ while the third model - the "multigeneration model"-suggests that a heavy tax on bequests will substantially reduce savings. ${ }^{138}$

Further empirical uncertainty involves whether and how savings are affected by changes in the rate of return-the after-tax interest rate. The question seems to be a variation on the age-old question of the relative magnitude of the so-called income and substitution effects: To what extent will people consume more if savings are taxed, and to what extent will they save more to make up for losses due to the tax? For many years

129. Americans Saving Less Now Than Before the '81 Tax Act, N.Y. Times, Sept. 6, 1983, at A1, col. 2.

130. H. AARON, supra note 119 , at 2 .

131. Id. at 10 .

132. Id.

133. Id. at 113 .

134. Id. at $23-25$.

135. The life-cycle hypothesis assumes that individuals plan to spend their entire lifetime income while they are alive. $I d$. at 12 . Bequests occur only because individuals guess incorrectly about their lifespan, id.; taxes on estates or gifts do not affect their plans. The short-horizon model assumes that because of informational constraints, individuals plan only a few years ahead, id. at 24 , and thus that they pay little attention to their estate until late in life.

136. Id. at 20-23. The multigenerational model assumes that an individual gains utility from the consumption that others undertake because of the individual's bequest. $I d$. at 21 . Because taxes on bequests affect the net consumption provided to others by a given gross bequest, the individual in the multigenerational model will change her behavior with changes in estate tax rates. See Kotlikoff \& Summers, The Role of Intergenerational Transfers in Aggregate Capital Accumulation, $89 \mathrm{~J}$. PoL. ECON. 706, 707 (1981). 
empirical results were conflicting, ${ }^{137}$ but the best recent evidence seems to suggest that savings is positively related to the real after-tax rate of interest (after adjusting for inflation). ${ }^{138}$ This finding has, of course, provided impetus for proposals to reduce a wide variety of taxes on capital and income from capital, including not only the estate tax, but also taxes on amounts saved for retirement, on capital gain, and on corporate income. ${ }^{139}$

The overall impact of such tax reductions on capital formation, however, will tend to depend upon other factors-most notably other aspects of fiscal and monetary policy. Monetary policies will, of course, affect the real rate of interest and the effects of changes in such policies may well overwhelm the impact of a tax reduction, especially a reduction in a relatively minor tax imposed at an uncertain future time, such as a deathtime tax on wealth. Moreover, the effect of any tax reduction on capital formation will vary depending upon how the additional tax revenues would have been used. If the taxes were used to reduce the deficit-say, by paying interest on the national debt, interest which now amounts to more than $\$ 100$ billion a year ${ }^{140}$ - the negative impact of the increased taxes on the rate of return to savings might be partially, fully, or more than offset by the positive effect on capital formation of reduced deficits and government debt.

It seems that modern economics has done little to improve upon Max West's characterization of this debate in his 1908 book on the inheritance tax. ${ }^{141}$ After noting the objections of Adam Smith and Ricardo, among others, to inheritance taxes on the grounds that they are "taxes on capital, and hence tend to diminish the national wealth," he characterized their objections as "really demolished" by John Stuart Mill, whom he quoted as stating:

The argument cannot apply to any country which has a national debt, and devotes any portion of revenue to paying it off; since the

137. See Howrey \& Hymans, The Measurement and Deternination of Loanable-Funds Saving, in What SHould BE TAXED?, supra note 80, at 9-17 (reviewing empirical studies).

138. See, e.g., Boskin, Taxation, Saving, and the Rate of Interest, 86 J. PoL. Econ. S3, S3-S27 (1978); David \& Scadding, Private Sazings: Ultrarationality, Aggregation and "Dennison's Law," 82 J. Pol. ECON. 225, 225-49 (1974); Taylor, Saving Out of Different Types of Income, 2 Brookings Papers on Econ. Activity 383, (1971); Wachtel, Inflation, Uncertainty, and Savings Behavior Since the Mid-1950's, 4 Explorations in ECON. ResEARCH 558 (1976).

139. See supra p. 273; Staff of the Joint Comm. on Taxatron, 97th Cong., 2d Sess., Pamphlet Analyzing Flat-Tax Proposals Considered at Senate Finance Committee Hearings on Sept. 28, 1982, reprinted in DaILY TAX REP. (BNA) No. 188, at J-1 (Sept. 28, 1981); An Analysis of FlatRate Taxes, 15 TAX Notes 951 app. (1982).

140. The Treasury Department estimates that the interest on the national debt will be $\$ 128.2$ billion for fiscal year 1983. See Dep't of the TREASURY, TREASURY BULLETIN: 3Rd QUARTER FrsCAl 1983, at 7 (1983).

141. M. West, The Inheritance Tax 189-234 (2d ed. 1908). 
produce of the tax, thus applied, still remains capital, and is merely transferred from the tax-payer to the fundholder. ${ }^{142}$

By the same token, if a tax on bequests replaces other taxes on capital or capital income, the net impact on savings might well prove beneficial. If, for example, estate tax revenues were used to reduce lifetime personal income taxes on capital income or corporate income taxes, a tax on capital transferred at death might well enhance, rather than retard, productivity and economic growth. ${ }^{143}$ Henry Aaron recently characterized the debate over Social Security:

Economists, who are no more immune to hunches than anyone else, have applied the tools of their discipline to try to determine which of these hunches [about how Social Security affects savings] is correct.

The evidence is conclusive that so far they have failed. Using the best that economic theory and statistical techniques have to offer, they have produced a series of studies that can be selectively cited by the true believers of conflicting hunches or by people with political agendas that they seek to advance.

. . . [T] he evidence falls grossly short of establishing the size, or even the direction, of the effects of Social Security on capital formation .... 14t

The evidence concerning the alleged adverse economic effects of the estate tax is far less extensive but equally inconclusive. Liberal economists will likely find little or no impact; conservative economists will probably discover serious deleterious effects. On balance, however, the economic evidence available to date simply fails to make a case for the elimination or reduction of estate and gift taxes on the grounds that increased savings will result. Other considerations must dominate such decisions. Persons who wish to increase the rate of capital accumulation would likely do better to focus on reducing federal deficits, stimulating business investment, and eliminating income tax incentives for inefficient investments.

142. Id. at 209. In a modern economics text, Richard and Peggy Musgrave make a related point: "[W]e have seen that $\$ 1$ of both tax and loan finance reduces private expenditures by $\$ 1$, but that tax finance is more likely to fall on private consumption, whereas loan finance will tend to fall on investment." R. Musgrave \& P. Musgrave, supra note 72, at 708. Of course, neither the Mill argument nor the Musgraves' point addresses the contention that an estate tax will so upset incentives that leisure will be substituted for productive activity and the private capacity to save will thereby be diminished.

143. Auerbach has even suggested that an income tax on excess returns above a safe rate of return may have no real cconolinic effects. Auerbach, supra note 120, at 935.

144. H. AARON, supra note 119, at 51-52. 


\section{What Does This Mean for the Estate Tax?}

So where does the foregoing leave me? First, confirmed in my view that progressive taxation complies with notions of fairness-that it is just and should not now be abandoned. Second, with the belief that a tax on bequests-an estate tax-can and should play an important role in achieving progressivity in the federal tax system; indeed, with the conviction that taxes on bequests are preferable to high tax rates on income as a means of achieving progressivity. Finally, with the view that there is no convincing evidence that the advantages of taxing bequests as a means of obtaining progressivity in taxation are overcome by the deleterious impact of estate taxes on capital formation. It is my view, therefore, that the nation's tax laws should move in the direction of the 1976 legislation, not that of the 1981 law, and that the estate tax should be rejuvenated and returned to its prior status as an important contributor to the progressivity of the tax system. But having urged this as the direction it should go, I cannot close without also examining where it will likely go.

There are two practical barriers to my preferred course of strengthening the role of the estate tax in the federal system. The first I have already described-namely the inherent limitation on the revenue potential of an estate tax. As I have detailed above, there simply is not enough wealth transferred annually to permit a wealth transfer tax (an estate and gift tax) to become a significant source of federal revenue. Given the current and projected levels of federal deficits, only substantial revenue sources seem likely to dominate the political agenda in the near-term. Thus, tax increases grounded predominately on distributional fairness would seem to have little chance of success.

The second practical barrier is that-for reasons which remain quite mysterious to me-taxation of bequests is extremely unpopular politically. The political obstacles take a variety of forms. It is often said that opponents of tax increases hide behind selected widows. Even with the unlimited marital deduction, when one considers estate taxation, both widows and orphans are readily at hand. The fact that most heirs of wealthy decedents are rich adults ${ }^{145}$ has little or no political significance.

A more important political obstacle to estate taxation lies in the objections of owners of small businesses and farms. These two groups produced the political momentum for both the 1976 and 1981 increases in the level of tax-exempt estates, ${ }^{148}$ and will (effectively, no doubt) resist any political efforts to reverse that trend. Although the estate tax does pose liquidity

145. 1976 Estale and Gift Tax Hearings, supra note 2, at 1233, 1234 (statement of Michael Graetz).

146. Sep Gutman, supra note 31, at 1198. 
problems for some owners of small businesses and farms, their clout far outweighs their actual stake in general estate tax policies. ${ }^{147}$ The great bulk of assets transferred at death by people subject to the estate tax has always been composed of liquid and readily marketable assets, principally securities. ${ }^{148}$ Nevertheless, coherent and progressive estate tax revision seems quite unlikely unless the political obstacles posed by farmers and owners of small businesses are neutralized.

The most puzzling political obstacle to estate tax revision, however, is that the American people do not seem to like heavy taxes on bequests. George McGovern's proposal in $1972^{\mathbf{1 4 9}}$ to confiscate inheritances above a certain amount was not well received, and a recent California initiative to repeal the state's inheritance tax garnered a sixty-four percent positive vote. ${ }^{180}$ This was a greater majority than those in favor of a nuclear freeze or against gun registration, issues on a subsequent initiative ballot. ${ }^{111}$ The only convincing explanation that has occurred to me for this phenomenon lies in the optimism of the American people. In California, at least, sixtyfour percent of the people must believe that they will be in the wealthiest five to ten percent when they die.

The combination of these political obstacles to the estate tax's rejuvenation and the tax's inherent limitations as a significant revenue source leads me to conclude that the estate tax seems far more likely to wither than to grow stronger. As I have suggested, this prediction makes me fear the demise of progressive taxation in the United States. In the long term, rescuing progressivity may require enactment of a periodic low-rate wealth tax, a tax that is now in place in many European nations and that enjoys significant revenue potential and substantial economic advantages over high marginal tax rates on the income from capital. ${ }^{162}$ Developing the case for a wealth tax, however, is a subject for another article.

If my prediction (as opposed to my desire) is fulfilled, and the years ahead complete the demise of the estate tax, the federal tax system will have lost more than an important and useful mechanism for achieving

147. Gutman reports that only seven percent of the gross value of assets subject to transfer taxation is attributable to farmers and owners of small businesses. Id. at 1210 .

148. 1976 Estate and Gift Tax Hearings, supra note 2, at 1311, 1319-20 (statement of James Smith).

149. Washington Post, Aug. 30, 1972, at A-11, col.1.

150. L.A. Times, June 10, 1982, pt. 1, at 16.

151. L.A. Times, Nov. 4, 1982, pt. 1, at 16.

152. The European countries with wealth taxes as of 1976 were Austria, Denmark, Finland, West Germany, Ireland, Luxembourg, the Netherlands, Norway, and Sweden. Dobson, An Analysis of European Wealth Taxes, 30 Bul.. INT'L Fiscal Doc. 231 (1976), reprinted in S. SuRREY, W. Warren, P. McDaniel \& H. Gutman, Federal Wealth Transfer Taxation 1140 (1977); see also Cooper, Taking Wealth Taxation Seriously, 34 REC. A.B. CrTY N.Y. 24 (1979). But see Verbit, Taking Wealth Taxation Seriously, 60 B.U.L. Rev. 1, 14 (1980) (describing European wealth taxes as "in decline"). 
progressivity; it will have lost a source of great humor. No longer will we hear the laughter of students or colleagues when we relate stories of the advantages of tax-savings gifts knowingly made in contemplation of death, or of antics such as those of Mrs. Stowe, who won her contemplation-ofdeath case because at age eighty, no doubt on the advice of her lawyer, she proved her life-related motives by dancing the night away at the St. Regis Hotel. ${ }^{163}$ In fact, just the other day, I heard today's version of thoughtful estate planning advice in the office of a well-known New York practitioner. A client had asked with great anxiety what he might do to minimize the estate taxes of his ninety-year-old widowed mother who had a large fortune, composed of extremely valuable art and cash. The lawyer thought for a great long while, no doubt running through his bag of estate planning tricks, when all of a sudden, with a gleam in his eye, he looked up and said calmly, "Marry her."154 It would be a real shame if a tax which produces such creative advice were to disappear.

153. Estate of Stowe, 31 T.C.M. (CCH) 432 (1972).

154. The advice came from T.A. Kurz, Debevoise \& Plimpton. See S. NAIFeh \& G. SmIth, The. BeST LAWYERS IN AMERICA 88 (1983). A truly prudent attorney would have said, "Find a state in which you can marry her." 